\title{
O Sol do Brasil: Nicolas-Antoine Taunay e as desventuras dos artistas franceses na corte de D. João
}

\author{
Bruna Oliveira Santiago*
}

Com a Escola dos Annales, pode-se dizer que a pesquisa histórica foi agraciada com uma nova perspectiva acerca dos objetos a serem estudados. O debate com outras áreas de fronteira foi valorizado. São os "bons vizinhos", como diria Robert Darnton. Essa noção enriqueceu a forma como contemplamos os homens do passado. Quanto ao estudo das imagens, é possível observá-las a partir de um ponto de vista que procura entender o universo cultural de quem as produziu, com a noção de relativização que a Antropologia nos ensina.

Peter Burke ${ }^{1}$ analisa o amplo uso das imagens como fonte histórica. Sobre as imagens em si, ele diz: "Elas são testemunhos dos estereótipos, mas também das mudanças graduais, pelas quais os indivíduos ou grupos vêem o mundo social, incluindo o mundo de sua imaginação". (BURKE, 2004, p. 232). O autor propõe ainda que as imagens complementam ou mesmo apoiam os documentos escritos, assim como podem destacar aspectos que não podem ser captados pela evidência escrita.

Na obra O Sol do Brasil, Lilia Moritz Schwarcz² realiza um profícuo estudo da obra de Nicolas-Antoine Taunay, pintor que veio para o Brasil na chamada Missão Francesa ${ }^{3}$. Logo na introdução, a autora faz uma reflexão crítica sobre o que seria a Missão Artística e por que ela existiu.

A ênfase do estudo recai sobre a figura de Taunay. O livro inicia com a carta que ele remeteu a D. João, oferecendo seus serviços. As obras de Taunay, bem como sua trajetória, demonstram que a cultura foi ao mesmo tempo um fator de limitação e inovação.

Schwarcz promove uma discussão a respeito do empreendimento denominado "Missão Francesa", responsável por trazer artistas para o trópico. Através da análise de inúmeras fontes, a autora sugere que a Missão não foi exatamente contratada pelo Estado Português, e sim foi uma espécie de autoconvite por parte dos franceses. E, ao contrário do que possa parecer, não se trata de um grupo coeso. As contradições iriam se acirrar alguns anos depois.

Em primeiro lugar, Lilia Schwarcz discorre sobre o contexto artístico na França do século XVIII. Em função de novos direcionamentos que a arte francesa tomou no que diz respeito à paisagem e à busca por inovações no cenário, uma viagem a territórios desconhecidos tornou-se elemento quase indispensável. "O artista dos arredores de Paris, da Roma antiga e das telas militares napoleônicas preparava-se para uma nova paisagem: os trópicos desconhecidos e imaginários do Brasil". (SCHWARCZ, 2008, p. 157).

Como pintor de paisagem, Taunay desenvolveu no Brasil trabalhos de maestria ímpar, repletos de detalhes que nos permitem compreender o estranhamento de um

*Bacharel e licenciada em História, pela Pontifícia Universidade Católica do Rio Grande do Sul PUCRS -

${ }^{1}$ BURKE, Peter. Testemunha Ocular: imagem e história. Bauru: EDUSC, 2004. 264 p.

${ }^{2}$ Lilia Moritz Schwarcz é historiadora e antropóloga, professora titular do departamento de antropologia da USP - Universidade de São Paulo - a autora de vários títulos.

${ }^{3} \mathrm{~A}$ Missão Francesa, que chegou ao Rio de Janeiro em 1819, consistiu numa expedição com o objetivo de fundar a primeira Academia de Arte no Reino Unido de Portugal, Brasil e Algarves. Era composta por artistas como JeanBaptiste Debret, NicolasAntoine Taunay, Auguste Marie Taunay, Grandjean de Montigny, CharlesSimon Pradier. Missão Artística Francesa. Disponível em: <http:// w w w. it a ucultural. org.br/aplicexternas/ enciclopedia_ic/index. $\mathrm{cfm}$ ?fuseaction $=$ marcos texto \&cd_verbete $=340$ http://www.itaucultural. org.br/aplicexternas/ enciclopedia_ic/index. $\mathrm{cfm}$ ?fuseaction $=$ marcos $\mathrm{t} e \mathrm{x} \mathrm{t} \& \mathrm{c} d$ verbete $=340 \mathrm{http}: / /$ www.itaucultural. org.br/aplicexternas/ enciclopedia_ic/index. $\mathrm{cfm}$ ?fuseaction $=$ marcos texto\&cd_verbete $=340>$ Acesso em: 1 abr. 2013. 
pintor formado na tradição francesa, que aportou em um ambiente luminoso e diverso de tudo o que estava habituado. $\mathrm{O}$ sol era demasiado forte e, as cores, diferentes.

A obra de Taunay é marcada por características que revelam uma interpretação imbuída, como não poderia deixar de ser, de elementos oriundos de sua cultura. Como a própria autora salienta, "fatos visuais são construções imaginárias". (SCHWARCZ, 2008, p. 247). A escravidão, por exemplo, era algo difícil de retratar: Taunay sempre representava os escravos como uma mancha escura na tela. Isso se explica justamente pelo fato de ser algo novo para ele. Outro exemplo é com relação à paisagem tropical: em algumas obras, as casas cravadas na paisagem poderiam ser confundidas com as cidades italianas.

Outra característica interessante da pintura de Taunay é a presença de animais em diversas obras, um cachorro observando a cena ou uma vaca que pasta calmamente. Tal fator evidencia alguma forma de intimidade do pintor com o ambiente no qual se encontrava, apesar de se sentir pouco à vontade. Nos termos utilizados por Schwarcz, Taunay tinha suas lentes culturais. Pode-se afirmar que: "Taunay mantém-se sempre como um observador longínquo, que se deixa contaminar pela paisagem local mas a traduz em seus próprios termos. Estava no Brasil, mas permanecia de certo modo na Europa". (SCHWARCZ, 2008, p. 273).

Antes de sua viagem para o Brasil, que duraria cinco anos, Taunay era um membro reconhecido no ambiente acadêmico francês. No entanto, em certo momento de sua vida, viu como única saída possível a ida para os "trópicos improváveis". Porém, ele sempre teve em mente a volta para seu país de origem, concebendo a viagem como algo transitório. "Tudo levava Taunay a decidir voltar para a França, de onde espiritualmente nunca se ausentara; só cumpria e respeitava a licença que pedira ao Institut de France". (SCHWARCZ, 2008, p. 282).

A partir de um trabalho de pesquisa rigoroso, Schwarcz compõe esta obra magistral que versa sobre a trajetória de Taunay e os artistas franceses no território brasileiro. Ela mostra que a "Missão Francesa" não foi um convite da Corte, e sim iniciativa de um grupo determinado a sair de uma França convulsionada com o objetivo de levar a civilização aos trópicos. A autora desenvolve a obra sob um viés antropológico e com a utilização de um sólido arcabouço teórico e documental tendo, no fim, um livro completo e muito bem estruturado. 